Agro-Science Journal of Tropical Agriculture, Food, Environment and Extension Volume 9 Number 2 May 2010 pp. $76-83$

ISSN 1119-7455

\title{
PROFILE DISTRIBUTION OF CLAY, Ca, Mg AND K IN SOME SOILS OF THE SAVANNA REGION OF NIGERIA
}

\author{
Obi $^{1}$, J. C*, Akinbola ${ }^{2}$, G. E., Ogunkunle ${ }^{2}$, A. O. and Umeojiakor ${ }^{2}$, A. O. \\ ${ }^{1}$ Department of Soil Science, University of Uyo, Uyo, Nigeria. \\ ${ }^{2}$ Department of Agronomy, University of Ibadan, Ibadan, Nigeria.
}

\begin{abstract}
Clay content and ratios of exchangeable cations are highly dependent on characteristics of soil parent material and deferential effect of weathering/leaching. Calcium (Ca) and magnesium (Mg) contents of soils are significantly correlated, and Mg content affects some soil physical characteristics and erodibility. The objective of this study was to establish a relationship between the distribution of clay, $\mathrm{Mg}, \mathrm{Ca}, \mathrm{K}$ and their ratios in some Nigerian soils. A total of 72 profile pits were prepared in 7 locations distributed in Niger, Edo, Oyo, Ogun and Osun States in the savanna region of Nigeria. The soils (comprising 49 Alfisols, 16 Entisols, 4 Ultisols, 2 Vertisols and 1 Inceptisol) were formed on shale/limestone, sandstones or basement complex (coarse-grained granites, coarse grained granite gneisses or amphibolites) materials. There was significant correlation among the textural separates $\left(r^{2} \geq\right.$ $0.21 \leq 0.96 ; p \leq 0.05 \leq 0.01), C a, M g$ and $K$ content $\left(r^{2} \geq 0.29 \leq 0.91 ; p \leq 0.05 \leq 0.01\right)$ of the soils. Correlation between clay and the ratios of exchangeable cations was significant in two locations $\left(r^{2} \geq\right.$ $0.38 \leq 0.77 ; p \leq 0.05 \leq 0.01)$. Regression equation established that profile distribution of clay was highly influenced by magnesium content $\left(r^{2} \geq 0.73 \leq 1.00, p \leq 0.05 \leq 0.01\right)$ of the soil and summarized for the entire locations as clay $=752.41+22.90(\mathrm{~K})-0.51($ silt $)-0.76($ sand $)-19.48(\mathrm{Ca} / \mathrm{K})-19.24(\mathrm{Mg} / \mathrm{K})+$ 19.65 $((\mathrm{Ca}+\mathrm{Mg}) / \mathrm{K})), r^{2}=0.83$ and $\mathrm{p}<0.05$. Mg content irrespective of the concentration of other exchangeable bases could be a strong factor in the profile distribution of clay, weathering/leaching, soil physical characteristics and stability of landscapes.
\end{abstract}

Keywords: Exchangeable cations, Ca:Mg:K ratios, clay migration, particle size distribution, Nigerian soils

\section{INTRODUCTION}

The relative levels of cations in the exchange complex are found to be more important than the absolute quantities in relation to crop response (Voortman, 1985), because there is always interactions between $\mathrm{Ca}, \mathrm{Mg}$ and $\mathrm{K}$. The ratios of the elements could more easily express imbalances compared to their absolute quantities. This is because, the activites of the cations are largely independent of their total concentrations but on their ratios which are characteristics of the parent material and subsequently soil as the values of these ratios are dependent on their proportions in the parent material and the differential effect of weathering/leaching (age) (Voortman et al., 2002; Olatunji et al. 2007) indicating direct relationship between weathering, CEC and clay. The ratio of cation exchange capacity (CEC) and percent clay expressed in percentage (i.e. clay activity) has been used as index of weathering and age. The size of the exchange site is called cation exchange capacity (CEC) which is defined as the measure of negatively charged sites on the clay-humus molecules or the exchange complex which is normally occupied by $\mathrm{Ca}, \mathrm{Mg}, \mathrm{K}, \mathrm{Na}$ (and sometimes in acid soils ferrous) ions. It was already established that calcium dominates the exchange site (Enloe et al., 2005) and that the ideal cation exchange balance for optimum crop performance is 76/18/6. Irrespective of the concentration of other exchangeable cations in the soil, it has been reported that $\mathrm{Mg}$ influences clay dispersion proportionately to its concentration in the exchange site (Dontsova and Norton, 2001, 2002, Yilmaz et al. 2005) Negative effects of Mg (intrinsic or extrinsic) on soil structure have been established. This is probably as a result of great quantity of hydration energy and subsequently hydration radius of $\mathrm{Mg}$ compared to $\mathrm{Ca}$ (Bohn, et al. 1985). These results in larger separation distance between clay layers and reduced attraction between them to cause flocculation. It had also been reported that high percentage of $\mathrm{Mg}$ 
on exchange sites had deteriorated soil structural properties and lowered infiltration rates compared to similar soils with high $\mathrm{Ca}$ content (Dontsova and Norton, 1998) This study therefore tried to establish a relationship between clay, calcium, magnesium and potassium in soils formed on basement complex, shale/limestone and sandstones which are the dominant parent material in Nigeria.

\section{MATERIALS AND METHODS}

Three locations were selected in the savanna region of Nigeria. They include Papalanto 1 and 2, (Ogun State), Ibadan (Oyo State), Ede (Osun State), Bacita and Mokwa (Niger State) and Ogwa (Edo State) as shown in Fig. 1. Papalanto was enclosed within latitudes $6^{\circ} 53^{\prime}$ and $6^{\circ} 54^{\prime} \mathrm{N}$ and longitudes $3^{\circ} 10^{\prime}$ and $3^{\circ} 12^{\prime} \mathrm{E}$, Ede was enclosed within latitudes $7^{\circ} 40^{\prime}$ and $7^{\circ} 45^{\prime} \mathrm{N}$ and longitudes $4^{\circ} 25^{\prime}$ and $4^{\circ} 30^{\prime} \mathrm{E}$, while Ibadan was enclosed within latitudes $7^{\circ} 30^{\prime}$ and $7^{\circ} 35^{\prime} \mathrm{N}$ and longitudes $3^{\circ} 45^{\prime}$ and $4^{\circ} 00^{\prime} \mathrm{E}$, Bacita and Mokwa were enclosed within latitudes $8^{\circ} 30^{\prime}$ and $11^{\circ} 00^{\prime} \mathrm{N}$ and longitudes $3^{\circ} 50^{\prime}$ and $5^{\circ} 11^{\prime} \mathrm{E}$ and Ogwa was enclosed within longitudes $6^{\circ} 11^{\prime}$ and $6^{\circ} 13^{\prime} \mathrm{E}$ and latitudes $6^{\circ} 30^{\prime}$ and $6^{\circ} 34^{\prime} \mathrm{N}$. The annual rainfall ranges between $1175 \mathrm{~mm}$ and $1600 \mathrm{~mm}$, while temperature ranges between $28^{\circ} \mathrm{C}$ and $35^{\circ} \mathrm{C}$, vegetation was savanna (dry and moist) and soils fall within the area classified by Smyth and Montgomery (1962) as basement complex soil and Moss (1957) as sedimentary soils. The intensity of rainfall regime between the States decreases from Niger < Oyo $\leq$ Edo $\leq$ Osun < Ogun.

Soils in the area were detailedly studied in auger holes and various soil series were identified as classified by Smyth and Montgomery (1962) and Moss (1957) for basement complex and sedimentary soils respectively. Profile pits were prepared, described and sampled according to genetic horizons for characterization and classification according to Keys to Soil Taxonomy (FAO/IUSS, 2006, Soil Survey Staff, 2006). The soil samples were air dried, crushed and made to pass through $2.0 \mathrm{~mm}$ mesh sieve. Particle size analysis was performed using the Bouyoucous hydrometer method (Gee and Bauder, 1986). Exchangeable bases were extracted with Mehlick No. 3 extraction (Mehlick, 1984). Potassium (K) content was read with the aid of flame emission spectroscopy, while calcium $\left(\mathrm{Ca}^{2+}\right)$ and magnesium $\left(\mathrm{Mg}^{2+}\right)$ were read with the aid of atomic absorption spectroscopy (AAS). Data collected were summarized using descriptive statistics and normality of the distribution was tested with skewness and kurtosis. Correlation and multiple regression analyses were carried out to find out the way variables relate with each other. All statistical analysis was carried out with the aid of SAS (1999).

\section{RESULTS AND DISCUSSION}

The mean and median were used as primary estimates of central tendency, while standard deviation, skewness, kurtosis, minimum and maximum were used as estimates of variability (Table 1). The descriptive statistics indicated that the distribution of particle sizes, exchangeable calcium $(\mathrm{Ca})$, magnesium $(\mathrm{Mg})$, potassium $(\mathrm{K})$ and their ratios were not very similar with each other (Table 1). However, this was to be expected because discrepancies between the surface and subsurface horizons were anticipated especially in profiles that display marked evidence of argillic horizons as could be found in Alfisols and Ultisols. Additionally, profile distribution of the variables in Vertisols and Entisols will equally vary from each other and from those that may have argillic horizons. It was observed that many of the variables were either skewed or kurtous in the entire sites. Also, it had been previously reported that soil properties normally display skewed or log normal distribution (Parkin and Robinson, 1992, Cambardella et al., 1994, Shukla et al., 2004, Iqbal, et al., 2005 and Obi and Ogunkunle, 2009). Yet, it was only in few instances that the mean and median are reasonably different from each other.

These were indications that outliers did not dominate the measures of central tendency, but true indication of soil properties distribution. To enhance pragmatic aspect of the study, no transoformation was attempted in as much as Parkin and Robinson (1992) had previously reported that many soil properties are log-normally distributed. It had been reported that variability of soil properties could be as a result of intrinsic (factors of soil formation), extrinsic (management and land use) variation or experimental error (Shukla, et al. 2004, Souza, et al., 2009, Botros., et al. 2009). But in this study effort was made to reduce error to the barest minimum. It was also anticipated that management imposed variation was either absent of very minimal to influence the exchangeable bases in the study sites because farming activities were under peasant and subsistence practice with little or no fertilizer application (Obi et al. 2008). Therefore, the observed variations indicated by the measure of central tendency could actually be mainly due to intrinsic variation. Additionally, it was assumed that if the descriptive statistics were carried out on the basis of horizons, probably the variables would have been more normally distributed. 


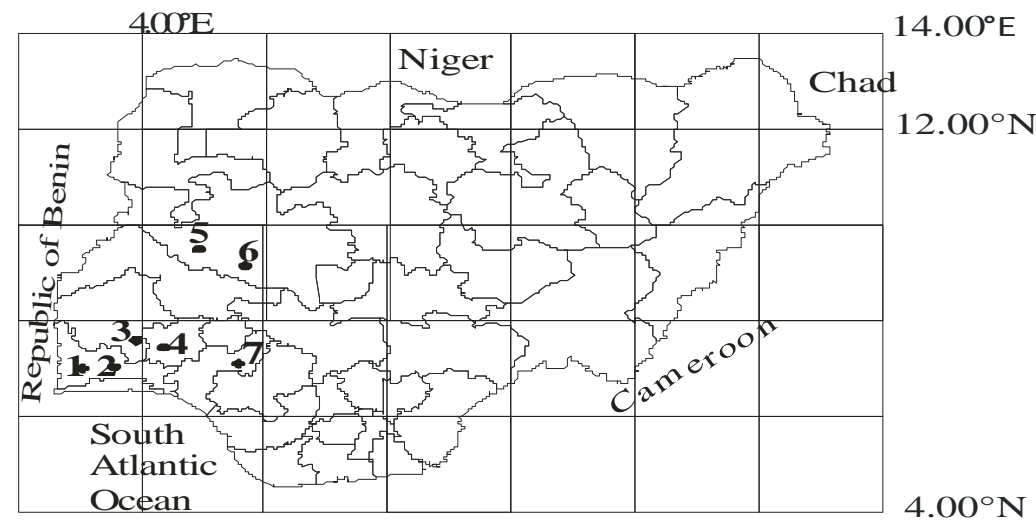

Legend

1 - Papalanto 1

2 - Papalanto 2

3 - Ibadan

4 - Ede

5 - Bacita

6 - Mokwa

7 - Ogwa

Fig. 1: Map of Nigeria showing locations of soil sample collection

The trend observed in the profile distribution of the cations were $\mathrm{Ca}>\mathrm{Mg}>\mathrm{K}$ with the exception of site 2, where the mean $\mathrm{Mg}$ tended to be marginally higher than $\mathrm{Ca}$, but not on the minimum and maximum values that gave consistent values with the already established trend. Enloe et al (2006) stated that $\mathrm{Ca}$ dominate the exchange site with $\mathrm{Mg}, \mathrm{K}, \mathrm{NH}_{3}$ and $\mathrm{Na}$ having lower concentrations. The anomaly observed in the trend was probably as a result of the abnormally high amount of $\mathrm{Mg}$ in some horizons of the profiles which may be attributed to pedoturbation due to the influence of topography (i.e. erosional / depositional) and probably formation of texture contrast soils (Phillips, 2007) that could have mineralogical implications.

The soils formed on shale/limestone were found in sites 1 and 2 (i.e. Papalanto). In site 1, K correlated with clay $\left(r^{2}=0.36, p<0.05\right)$, while sand fraction correlated with $\mathrm{Ca} / \mathrm{Mg}$ and $\mathrm{Mg} / \mathrm{K}\left(\mathrm{r}^{2}=\right.$ $0.42, \mathrm{p} \leq 0.01$ and $-0.38, \mathrm{p}<0.05$, respectively). There was significant correlation between $\mathrm{Ca}$ and $\mathrm{Mg}\left(\mathrm{r}^{2}=0.367, \mathrm{p}<0.05\right)$. While in site 2 , clay significantly correlated with the entire variables but $\mathrm{K}$ as shown in Table 2. Potassium had previously displayed significant correlation with clay in site 1 . This helped to arrive at a possible conclusion that there was a significant correlation between the entire textural separates with the exchangeable bases ( $\mathrm{Ca}, \mathrm{Mg}$ and $\mathrm{K}$ ) in the soils formed on shale/limestone materials. The soil series involved included Abesse, Yewa, Ogun and Onikoko (Moss, 1957) corresponding to Arenic kandiudalf, Arenic kandiaqualf, Udic Hapludert and Typic udipsamments respectively of USDA Keys to Soil Taxonomy (Soil Survey Staff, 2006). Sites 3, 4 and 5 (i.e Ibadan, Ede and Bacita respectively) are soils formed on basement complex materials. They are soils derived mainly from coarse-grained granites, coarse-grained granite gneisses and amphibolites. The fine earth fractions of the soils usually contain higher proportion of coarse fragments compared to the shale/limestone soils. In sites 3 and 4, there was no significant correlation between any of the textural separates and the entire exchangeable bases considered in this study (i.e. $\mathrm{Ca}, \mathrm{Mg}$ and $\mathrm{K}$ ). Nevertheless, there was intercorrelation between the bases (i.e. $\mathrm{Ca}$ and $\mathrm{Mg}, \mathrm{r}^{2}=0.91, \mathrm{p}<0.01$; Ca and $\mathrm{K}, \mathrm{r}^{2}=0.46, \mathrm{p}<0.01 ; \mathrm{Mg}$ and $\mathrm{K}, \mathrm{r}^{2}=0.58$, $\mathrm{p}$ $<0.01$ ). In site 5 (Bacita), there was highly significant correlation between clay and $\mathrm{Ca}, \mathrm{Mg}$ and $\mathrm{K}\left(\mathrm{r}^{2}=0.50,0.58\right.$ and 0.67 respectively, $\mathrm{p}<$ 0.01 ), but not with their ratios. In addition, $\mathrm{K}$ correlated with sand and silt $\left(\mathrm{r}^{2}=0.38, \mathrm{p}<0.05\right.$ and -0.67 , respectively, $\mathrm{p}<0.01)$, while $\mathrm{Ca}$ and $\mathrm{Mg}$ did not correlate with silt but sand $\left(\mathrm{r}^{2}=-0.47\right.$, $\mathrm{p}<0.01$ and $-0.40, \mathrm{p}<0.05$ respectively). The particle sizes also significantly correlated with each other $\left(r^{2} \geq 0.38 \geq 0.96, p<0.05\right)$. The variations observed in the relationship between the particle sizes, $\mathrm{Ca}, \mathrm{Mg}$ and $\mathrm{K}$ of sites 3 and 4 compared to site 5 were indications that parent rock type and weathering affect the relationship among the variables (Shaw, et al. 2001, Voortman, et al. 1985, 2002). Variables of site 5 formed on amphiboles which are easily weathered and normally forms deep regolith behave more like other softer and more easily weathered parent materials of sedimentary origin. The soil series identified in sites 3 and 4 include Iwo (Arenic Kandiudalf), Iregun (Typic Hapludalf), Balogun (Vetrandic Hapludalf), Egbeda (Kanhaplic Rhodustalf), Matako (Typic Psammaquent), Ibadan (Arenic Kandiudalf), Apomu (Typic Psammaquent), Shepeteri (Plinthustalf), Olorunda (Typic Kanhapludalf), Jago (Tropaquent) and Makun (Arenic Kandiudalf). While those found in site 5 include Typic Paleudstalf, Arenic haplustalf, Aquic Ustorthent, Udic Haplustult and Typic quartzipsamment 
Table 1: Descriptive statistics of the distribution of exchangeable cations and particle sizes within the profiles at different study sites

\begin{tabular}{|c|c|c|c|c|c|c|c|c|c|c|c|c|c|c|c|c|c|}
\hline & Mean & Median & Min. & Max & Skewness & Kurtosis & SD & SE & & Mean & Median & Min & Max & Skewness & Kurtosis & SD & SE \\
\hline Site 1 & & & & & & & & & Site 2 & & & & & & & & \\
\hline $\mathrm{Ca}$ & 5.52 & 5.50 & 4.40 & 6.80 & 0.05 & -1.10 & 0.66 & 0.11 & & 5.56 & 5.02 & 2.34 & 11.0 & 0.48 & -0.94 & 2.53 & 0.42 \\
\hline Mg & 4.02 & 4.10 & 2.40 & 4.90 & -1.03 & 1.10 & 0.53 & 0.09 & & 5.76 & 5.16 & 2.14 & 10.1 & 0.30 & -1.50 & 2.71 & 0.45 \\
\hline $\mathbf{K}$ & 1.08 & 1.00 & 0.80 & 1.90 & 3.08 & 14.68 & 0.17 & 0.03 & & 0.17 & 0.69 & 0.56 & 0.92 & 0.48 & -1.03 & 0.10 & 0.01 \\
\hline Clay & 416.00 & 424.00 & 130.00 & 776.00 & -0.06 & -0.66 & 166.00 & 28.40 & & 263.00 & 254.00 & $\mathbf{5 4 . 0 0}$ & 614.00 & 0.28 & -0.35 & 142.00 & 23.7 \\
\hline Silt & 235.00 & 236.00 & 53.00 & 476.00 & 0.39 & -0.22 & 102.00 & 17.60 & & 138.00 & 114.00 & 54.00 & 354.00 & 1.39 & -1.51 & 76.00 & 12.68 \\
\hline Sand & 350.00 & 340.00 & 160.00 & 622.00 & 0.31 & -0.58 & 121.00 & 20.90 & & 491.00 & 552.00 & 94.00 & 892.00 & -0.08 & -1.55 & 281.00 & 46.97 \\
\hline $\mathrm{Ca} / \mathrm{Mg}$ & 1.40 & 1.34 & 1.07 & 2.45 .00 & 3.08 & 10.14 & 0.27 & 0.05 & & 1.01 & 0.94 & 0.66 & 1.80 & 1.25 & 1.53 & 0.25 & 0.04 \\
\hline $\mathrm{Ca} / \mathrm{K}$ & 5.20 & 5.28 & 2.68 & 6.30 & -1.54 & 5.08 & 0.66 & 0.11 & & 7.60 & 7.16 & 3.80 & 12.50 & 0.50 & -0.99 & 2.71 & 0.47 \\
\hline $\mathbf{M g} / \mathbf{K}$ & 3.78 & 3.91 & 2.00 & 4.50 & -1.79 & 3.65 & 0.55 & 0.09 & & 7.34 & 6.85 & 0.00 & 13.50 & 0.22 & -1.48 & 3.58 & 0.54 \\
\hline$(\mathbf{C a}+\mathbf{M g}) / \mathbf{K}$ & 8.98 & 9.09 & 4.68 & 10.63 & -2.04 & 7.99 & 1.03 & 0.18 & & 14.4 & 14.27 & 1.92 & 24.10 & 0.27 & -1.41 & 6.14 & 0.96 \\
\hline Site 3 & & & & & & & & & Site 4 & & & & & & & & \\
\hline $\mathrm{Ca}$ & 4.20 & 4.51 & 0.86 & 6.12 & -1.18 & 1.06 & $1 . .43$ & 0.25 & & 4.02 & 3.72 & 0.57 & 11.1 & 0.95 & 1.11 & 2.21 & 0.27 \\
\hline Mg & 3.34 & 3.59 & 0.06 & 5.70 & -0.99 & 0.15 & 1.50 & 0.26 & & 1.38 & 1.05 & 0.11 & 4.66 & 0.19 & 0.86 & 1.11 & 0.13 \\
\hline K & 1.13 & 1.14 & 0.56 & 1.61 & -0.21 & -0.05 & 0.25 & 0.04 & & 0.19 & 0.17 & 0.04 & 0.77 & 1.79 & 5.67 & 0.12 & 0.02 \\
\hline Clay & 165.00 & 143 & 28.00 & 673.00 & 2.51 & 8.77 & 122.00 & 21.70 & & 242.00 & 185.00 & 42.00 & 542.00 & 0.62 & -0.96 & 147.00 & 17.90 \\
\hline Silt & 113.00 & 70 & 18.00 & 896.00 & 4.72 & 24.59 & 151.00 & 26.70 & & 135.00 & 132.00 & 20.00 & 260.00 & 0.20 & 0.16 & 48.20 & 5.85 \\
\hline Sand & 734.00 & 778 & 237.00 & 954.00 & -1.56 & 3.80 & 142.00 & 25.20 & & 619.00 & 698.00 & 278.00 & 838.00 & -0.80 & 0.54 & 159.00 & 19.30 \\
\hline $\mathrm{Ca} / \mathbf{M g}$ & 1.91 & 1.22 & 0.86 & 14.30 & 4.84 & 25.25 & 2.39 & 0.42 & & 4.77 & 3.28 & 1.48.00 & 27.70 & 3.11 & 9.42 & 5.33.00 & 0.65 \\
\hline $\mathrm{Ca} / \mathrm{K}$ & 3.76 & 3.98 & 0.65 & 5.43 & -1.45 & 1.94 & 1.51 & 0.20 & & 23.4 & 21.6 & 7.37 & 92.00 & 2.34 & 8.58 & 19.70 & 1.67 \\
\hline $\mathrm{Mg} / \mathrm{K}$ & 2.90 & 3.23 & 0.10 & 4.20 & -1.55 & 1.38 & 1.13 & 0.20 & & 7.76 & 6.24 & 0.43 & 34.60 & 2.15 & 6.41 & 6.10 & 0.74 \\
\hline $\begin{array}{l}(\mathbf{C a}+\mathbf{M g}) / \mathbf{K} \\
\text { Site } 5\end{array}$ & 6.65 & 7.24 & 0.83 & 9.40 & -1.76 & 2.51 & 2.15 & 0.38 & Site 6 & 31.10 & 29.00 & 12.10 & 121.00 & 2.40 & 8.52 & 18.60 & 2.26 \\
\hline$\frac{\mathrm{Ca}}{\mathrm{Ca}}$ & 6.18 & 4.10 & 0.20 & 24.00 & 0.30 & -0.84 & 5.42 & 0.08 & & 4.95 & 4.91 & 3.99 & 6.04 & 0.26 & -0.74 & 0.54 & 0.08 \\
\hline Mg & 2.99 & 2.25 & 0.72 & 9.17 & -1.07 & 4.30 & 2.03 & 0.08 & & 3.23 & 3.21 & 1.00 & 4.20 & -1.29 & 4.97 & 0.55 & 0.08 \\
\hline $\mathrm{K}$ & 0.18 & 0.13 & 0.04 & 0.64 & 0.81 & -0.01 & 0.14 & 0.02 & & 0.81 & 0.80 & 0.67 & 1.03 & 0.62 & -0.43 & 0.09 & 0.01 \\
\hline Clay & 203.00 & 230 & 30.00 & 516.00 & -0.31 & -0.91 & 131.00 & 13.40 & & 188.00 & 174.00 & 54.00 & 354.00 & 0.15 & -1.00 & 87.60 & 13.30 \\
\hline Silt & 97.00 & 60.0 & 20.00 & 320.00 & 0.69 & -0.38 & 77.20 & 4.89 & & 56.30 & 54.00 & 14.00 & 134.00 & 0.57 & 0.55 & 34.40 & 5.24 \\
\hline Sand & 698.00 & 690 & 344.00 & 950.00 & 0.08 & -0.99 & 176.00 & 12.30 & & 757.00 & 772.00 & 552.00 & 892.00 & -0.32 & -0.97 & 95.90 & 14.62 \\
\hline $\mathrm{Ca} / \mathrm{Mg}$ & 2.35 .00 & 1.41 & 0.09 & 11.1.00 & 5.88 & 38.3 & 2.43 & 0.09 & & 1.61 & 1.52 & 1.14 & 5.71 & 5.80 & 36.40 & 0.66 & 0.10 \\
\hline $\mathrm{Ca} / \mathrm{K}$ & 41.00 & 25.0 & $\mathbf{3 . 3 3}$ & 157.00 & 0.00 & -0.13 & 39.40 & 0.13 & & 6.15 & 6.09 & 4.15 & 7.90 & -0.21 & -0.14 & 0.84 & 0.12 \\
\hline $\mathbf{M g} / \mathbf{K}$ & 21.40 & 17.8 & 4.56 & 83.3.0 & -2.73 & 14.00 & 15.80 & 0.08 & & 4.00 & 4.02 & 1.05 & 5.24 & -2.73 & 13.30 & 0.60 & 0.09 \\
\hline$(\mathbf{C a}+\mathbf{M g}) / \mathbf{K}$ & 62.00 & 45.5 & 19.10 & 171.00 & -0.21 & 0.44 & 44.60 & 0.18 & & 10.10 & 10.10 & 7.06 & 13.10 & $-\mathbf{- 0 . 3 0}$ & 0.71 & 1.20 & 0.18 \\
\hline $\mathrm{Ca}$ & 4.95 & 4.91 & 2.99 & 6.04 & 0.26 & -0.74 & 0.54 & 0.08 & & & & & & & & & \\
\hline Mg & 3.23 & 3.21 & 1.00 & 4.20 & -1.29 & 4.97 & 0.55 & 0.08 & & & & & & & & & \\
\hline K & 0.81 & 0.80 & 0.67 & 1.03 & -0.62 & -0.43 & 0.09 & 0.01 & & & & & & & & & \\
\hline Clay & 188.00 & 174.00 & 54.00 & 354.00 & 0.15 & -1.00 & 87.60 & 13.30 & & & & & & & & & \\
\hline Silt & 56.3 .00 & 54.00 & 14.00 & 134.00 & -0.57 & -0.55 & 34.40 & 5.20 & & & & & & & & & \\
\hline Sand & 757.00 & 772.00 & 552.00 & 892.00 & -0.32 & -0.97 & 95.90 & 14.60 & & & & & & & & & \\
\hline $\mathrm{Ca} / \mathrm{Mg}$ & 1.61 & 1.52 & 1.14.00 & 5.71 & 5.80 & 36.4 & 0.66 & 0.10 & & & & & & & & & \\
\hline $\mathrm{Ca} / \mathrm{K}$ & 6.15 & 6.09 & 4.15 & 7.90 & -0.21 & -0.14 & 0.84 & 0.12 & & & & & & & & & \\
\hline $\mathbf{M g} / \mathbf{K}$ & 4.00 & 4.02 & 1.05 & 5.24 & -2.73 & 13.3 & 0.60 & 0.09 & & & & & & & & & \\
\hline$(\mathbf{C a}+\mathbf{M g}) / \mathbf{K}$ & 10.50 & 10.1 & 7.06 & 13.10 & -0.30 & 0.71 & 1.20 & 0.18 & & & & & & & & & \\
\hline
\end{tabular}


Obi, J. C Akinbola, G. E., Ogunkunle, A. O. and Umeojiakor, A. O.

Table 2: Pearson correlation coefficients for soil properties of the profiles in sites 1 to 7

\begin{tabular}{|c|c|c|c|c|c|c|c|c|c|c|c|c|}
\hline & $\mathrm{Ca}$ & Mg & $\mathbf{K}$ & Clay & Silt & Sand & $\mathrm{Ca}$ & Mg & $K$ & Clay & Silt & Sand \\
\hline Site 1 & & & & & & & Site 2 & & & & & \\
\hline$\overline{\mathbf{C a}}$ & & & & & & & & & & & & \\
\hline Mg & 0.37 & & & & & & 0.86 & & & & & \\
\hline $\mathbf{K}$ & & & & & & & 0.71 & 0.57 & & & & \\
\hline Clay & & & -0.37 & & & & 0.51 & 0.75 & & & & \\
\hline Silt & & & & -0.69 & & & 0.76 & 0.58 & 0.54 & 0.35 & & \\
\hline Sand & & & & -0.79 & & & -0.67 & -0.77 & -0.46 & -0.77 & -0.45 & \\
\hline $\mathrm{Ca} / \mathrm{Mg}$ & 0.43 & -0.66 & & 0.43 & & & & -0.39 & & -0.55 & & 0.35 \\
\hline $\mathrm{Ca} / \mathrm{K}$ & & & -0.64 & & & & 0.96 & 0.86 & -0.51 & 0.55 & 0.75 & -0.67 \\
\hline $\mathrm{Mg} / \mathrm{K}$ & & 0.60 & -0.57 & & & & & 0.60 & & 0.57 & 0.36 & -0.47 \\
\hline$(\mathrm{Ca}+\mathrm{Mg}) / \mathrm{K}$ & & & -0.72 & & & & 0.44 & 0.61 & & 0.51 & 0.50 & -0.47 \\
\hline Site 3 & & & & & & & Site 4 & & & & & \\
\hline $\mathrm{Mg}$ & 0.91 & & & & & & 0.66 & & & & & \\
\hline $\mathbf{K}$ & 0.46 & 0.58 & & & & & 0.47 & 0.39 & & & & \\
\hline $\begin{array}{l}\text { Clay } \\
\text { Silt }\end{array}$ & & & & & & & 0.28 & & 0.38 & & & \\
\hline Sand & & & & -0.92 & & & & & & -0.96 & -0.41 & \\
\hline $\mathrm{Ca} / \mathrm{Mg}$ & -0.60 & -0.63 & -0.45 & & & & & -0.44 & & & & \\
\hline $\mathbf{C a} / \mathbf{K}$ & 0.78 & 0.57 & & & & & 0.51 & 0.31 & -0.37 & & & \\
\hline $\mathbf{M g} / \mathbf{K}$ & 0.84 & 0.90 & & & & & 0.44 & 0.75 & & & & \\
\hline$(\mathrm{Ca}+\mathrm{Mg}) / \mathrm{K}$ & 0.86 & 0.78 & & & & & 0.53 & 0.47 & -0.34 & & & \\
\hline$\underline{\text { Site } 5}$ & & & & & & & Site 6 & & & & & \\
\hline $\mathrm{Mg}$ & & & & & & & 0.67 & & & & & \\
\hline $\mathbf{K}$ & & & & & & & 0.29 & 0.38 & & & & \\
\hline Clay & 0.49 & 0.58 & 0.67 & & & & 0.52 & 0.82 & 0.29 & & & \\
\hline Silt & & & 0.38 & 0.38 & & & & & & 0.21 & & \\
\hline Sand & -0.47 & 0.40 & -0.67 & 0.91 & -0.72 & & -0.52 & -0.80 & -0.30 & -0.90 & -0.49 & \\
\hline $\mathrm{Ca} / \mathrm{Mg}$ & 0.91 & & & & & & 0.35 & -0.27 & & & & \\
\hline $\mathrm{Ca} / \mathrm{K}$ & 0.93 & & & & & & 0.85 & 0.46 & & 0.38 & & -0.39 \\
\hline $\mathrm{Mg} / \mathrm{K}$ & & 0.72 & 0.39 & & & & 0.46 & 0.75 & -0.21 & 0.64 & & -0.64 \\
\hline$(\mathrm{Ca}+\mathrm{Mg}) / \mathrm{K}$ & 0.82 & 0.36 & & & & & 0.72 & 0.68 & -0.21 & 0.57 & & -0.58 \\
\hline Site 7 & & & & & & & & & & & & \\
\hline $\mathrm{Mg}$ & & 0.47 & & & & & & & & & & \\
\hline $\mathbf{K}$ & & & & & & & & & & & & \\
\hline Clay & & & & & & & & & & & & \\
\hline Silt & & & & & & & & & & & & \\
\hline Sand & & & & -0.92 & & & & & & & & \\
\hline $\mathrm{Ca} / \mathrm{Mg}$ & 0.30 & -0.73 & & & & & & & & & & \\
\hline $\mathrm{Ca} / \mathrm{K}$ & 0.57 & & -0.66 & & & & & & & & & \\
\hline $\mathrm{Mg} / \mathrm{K}$ & & 0.70 & -0.30 & & & & & & & & & \\
\hline$(\mathrm{Ca}+\mathrm{Mg}) / \mathrm{K}$ & 0.47 & & -0.63 & & & & & & & & & \\
\hline
\end{tabular}

Table 3: Relative contribution (\%) of exchangeable cations and particle sizes to the distribution of clay within the profiles at different study sites

\begin{tabular}{llllllllll}
\hline Site & $\mathrm{Ca}$ & $\mathrm{Mg}$ & $\mathrm{K}$ & Silt & Sand & $\mathrm{Ca} / \mathrm{Mg}$ & $\mathrm{Ca} / \mathrm{K}$ & $\mathrm{Mg} / \mathrm{k}$ & $\mathrm{Ca}+\mathrm{Mg} / \mathrm{K}$ \\
\hline 1 & 0 & 43 & 0 & 39 & 19 & 0 & 0 & 0 & 0 \\
2 & 0 & 9 & 0 & 0 & 1 & 91 & 0 & 0 & 0 \\
3 & 0 & 0 & 63 & 0 & 1 & 0 & 0 & 36 & 0 \\
4 & 0 & 0 & 0 & 47 & 53 & 0 & 0 & 0 & 0 \\
5 & 0 & 0 & 0 & 50 & 50 & 0 & 0 & 0 & 0 \\
6 & 0 & 100 & 0 & 0 & 0 & 0 & 0 & 0 & 0 \\
7 & 85 & 0 & 0 & 8 & 8 & 0 & 0 & 0 & 0 \\
$*$ & 14 & 57 & 14 & 71 & 100 & 14 & 0 & 14 & 0 \\
* Occurrence & 14 \\
geccurrence implies the ratio of number of times each variable participated in a regression equation to the entire regression equation
\end{tabular}


Sites 6 and 7 are soils formed under cretaceous sandstones, they equally have higher quantities of coarse fragments compared to shale/limestones. In site 6 (i.e. Mokwa), the dominant soils include Typic Ustorthent, Aquic Ustorthent, Oxic Haplustalf, Aquic Haplustalf, Typic Eutropept, Typic Ustpsamment (series could not be classified). Clay content correlated with $\mathrm{Ca}, \mathrm{Mg}$ and $\mathrm{K}$ with $\mathrm{r}^{2}=0.52,0.82$ and 0.29 respectively $(\mathrm{p}$ $<0.05$ ). Additionally, sand correlated highly with $\mathrm{Ca}, \mathrm{Mg}$ and $\mathrm{K}\left(\mathrm{r}^{2}=-0.52,-0.80\right.$ and -0.30 respectively, $\mathrm{p}<0.01)$. Silt did not significantly correlate with any of the exchangeable cations considered in the study. There were significant correlations among $\mathrm{Ca}, \mathrm{Mg}$ and $\mathrm{K}$. Site 7 (i.e. Ogwa) comprising soils of Alagba, Ibeshe, Okpanam, Kulfo, Ngego, Onipepeye and Ahiara series corresponding to Typic Paleudults, Arenic Paleudult, Typic Paleaqult and Oxic Dystropept respectively. There was no correlation between clay, sand and silt and the exchangeable cations with the exception of $\mathrm{Mg}$ and $\mathrm{K}\left(\mathrm{r}^{2}=0.47\right.$, $\mathrm{p}<$ $0.01)$. It is noteworthy that there was significant correlation among the various textural separates in the entire sites with the exception of site 7 where correlation exists between sand and clay $\left(\mathrm{r}^{2}=0.92\right.$, $\mathrm{p}<0.01)$ alone. There were trends in the relative quantities of the exchangeable cations in the exchange site and significant correlations among the particle sizes, exchangeable bases and their ratios (Voortman et al. 2002; Obi and Ogunkunle 2008), and between the particle sizes, exchangeable bases and/or their ratios. Hence, it could be averred that there is always intercorrelation between $\mathrm{Ca}, \mathrm{Mg}$ and $\mathrm{K}$ and/or their ratios with soil textural separates. An important dimension in this study was the contributions of $\mathrm{Ca}$ and $\mathrm{K}$ apart rom $\mathrm{Mg}$ in influencing clay distribution in the profiles.

The effect of $\mathrm{Mg}$ on soil physical properties manifest itself on the surface of the soil in forms of sealing, crusting and erosion as reported by Donatova and Norton, (2001, 2002) and Yilmaz et al., (2005). Nevertheless manifestation of the influence of $\mathrm{Mg}$ on the physical properties of the soil profile include their effects of clay dispersion, infiltration, hydraulic conductivity, structural stability and erosion (Donatova and Norton, 2001, Donstova and Norton 2002, Yilmaz et al., 2005). It is important to note that there exists neither threshold value for the effect of $\mathrm{Mg}$ on soil dispersion nor minimum $\mathrm{Ca} / \mathrm{Mg}$ values for the effect of $\mathrm{Mg}$ on soil physical characteristics (Emerson and Chi, 1977). Hence, the difficulties in establishment of minimum quantity of magnesium that will meet minimal requirements for optimal crop growth and at the same time have minimal deteriorating effect on soil physical characteristics. It should be noted that $\mathrm{Mg}$ is an important macronutrient which plants require in adequate quantity for normal growth. According to Tisadale et al., (1993), there is a possibility of $\mathrm{Mg}$ deficiency when its content accounts for less than $10 \%$ of cation exchange capacity of the soil, but this value greatly depends on soil and crop type. Multiple regression analysis was carried out in order to establish individual contributions of the cations and their ratios to clay distribution within the profile, with clay as the dependent variable, while silt, sand, $\mathrm{Ca}, \mathrm{Mg}, \mathrm{K}$ and their ratios were used as independent variables and the following relationships were arrived at:

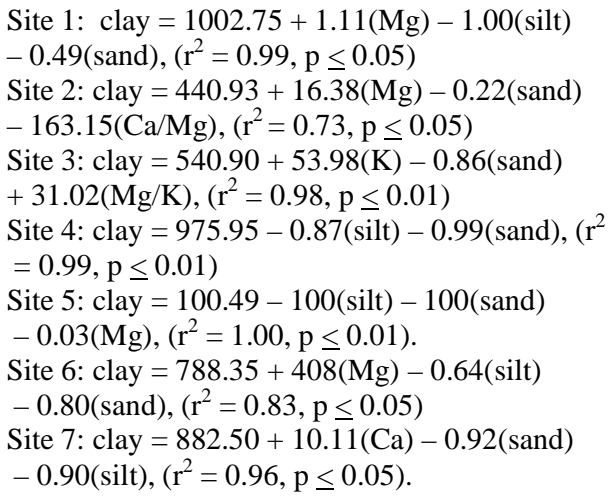

The relative contributions of each variable in the profile distribution of clay in the entire study areas were as shown in Table 3. The total occurrences of each variable in the regression equation for the entire sites were presented in percentage. It was observed that sand and silt had the highest frequency of occurrence (100 and 71 percent respectively), while $\mathrm{Ca} / \mathrm{K}$ and $\mathrm{Ca}+\mathrm{Mg} / \mathrm{K}$ did not occur in any. But these do not imply that $\mathrm{Ca} / \mathrm{K}$ and $\mathrm{Ca}+\mathrm{Mg} / \mathrm{K}$ were not contributing to the distribution of clay in the profile as these effects could at least be indirect as they significantly correlate with the other variables. Then integrating the entire relationships to arrive at a simple unified regression equation irrespective of parent material and rainfall regime the following equation was obtained: clay $=752.41+22.90(\mathrm{~K})-0.51($ silt $)-$ $0.76($ sand $)-19.48(\mathrm{Ca} / \mathrm{K})-19.24(\mathrm{Mg} / \mathrm{K})+$ $19.65((\mathrm{Ca}+\mathrm{Mg}) / \mathrm{K})), \mathrm{r}^{2}=0.83$ and $\mathrm{p}<0.05$. The relative contribution of the variables in the regression equation were as follows: $\mathrm{K}(27.8 \%)$, $\mathrm{Ca}+\mathrm{Mg}) / \mathrm{K}(23.8 \%), \mathrm{Ca} / \mathrm{K}(23.6 \%), \mathrm{Mg} / \mathrm{K}(23.3 \%)$, sand $(0.9 \%)$ and silt $(0.6 \%)$. These created the indication that it was magnesium alone among the exchangeable bases that consistently influenced 
the distribution of clay. Emerson and Chi (1977) and Curtin et al. (1994) reported that the difference in behaviour between $\mathrm{Ca}$ and $\mathrm{Mg}$ was due to a slightly greater hydrated radius of the $\mathrm{Mg}^{2+}$ ion (0.47 versus $0.42 \mathrm{~nm})$ and consequently lower electrostatic force with which a hydrated $\mathrm{Mg}^{2+}$ ion is held at the clay surface. This was further supported with the observation of a highly significant positive linear relationship between the percentage of $\mathrm{Ca}$ in soil solution and that on exchange site and light transmittance of clay suspension as a measure of flocculation in the soil. (Dotsova and Norton, 1999). Even in the locations where the ratios of exchangeable cations made contributions, it was not without $\mathrm{Mg}$ (i.e. $\mathrm{Ca} / \mathrm{Mg}$ or $\mathrm{Mg} / \mathrm{K})$. The integrated equation brought into the equation the ratio of $\mathrm{Ca}$ and $\mathrm{K}$ which highly significantly correlated with $\mathrm{Mg}\left(\mathrm{r}^{2} \geq 0.31 \leq 0.86\right.$, $\mathrm{p} \leq 0.01)$ in four out of the entire sites to further emphasize the effect of the relationship between the exchangeable bases in influencing clay migration/dynamics in the regolith as most exchange sites are fixed and dependent on the parent material (clay) and humus.

\section{CONCLUSION}

The soil properties were not normally distributed, yet outliers did not dominate the central tendency. There was correlation among the soil particle sizes, $\mathrm{Ca}, \mathrm{Mg}, \mathrm{K}$ and their ratios. There were correlations between the particle sizes, $\mathrm{Ca}, \mathrm{Mg}, \mathrm{K}$ and/or their ratios. $\mathrm{Mg}$ alone consistently influenced clay distribution within the profiles in majority of the locations. Therefore $\mathrm{Mg}$ irrespective of concentration of $\mathrm{Ca}$ and $\mathrm{K}$ could influence clay distribution within the profiles, affect soil physical properties.

\section{REFERENCES}

Botros, F. E., Harter, T, Onsoy, Y. S., Tuli, A. and Hopmans, J. W. (2009). Spatial variability of hydraulic properties and sediments characteristics in a deep alluvial unsaturated zone. Vadose Zone J. 8:276 - 289 .

Cambardlla, C. A., Moorman, T. B., Novak, J. M., Parkin, T. B., Karlan, D. L., Turco, R. F. and Konopka, A.E. (1994). Field scale variability of soil properties in Central Iowa soils. Soil Sci. Soc. Am. J. 58:15011511.

Curtin, D. Steppuhn, H. and Selles, F. (1994). Effect of magnesium on cation selectivity and structural stability of soidic soils. Soil Sci. Soc. Am. J. 58: 730 - 737.
Donstova, K. M and Norton, L. D. (2001). Effect of exchangeable $\mathrm{Ca}: \mathrm{Mg}$ ratio in soil clay flocculation, infiltration and erosion. In: Sustaining the Global Farm. Stott, D. E., Mohtar, R. H. and Steintardt, G. C. (eds.). Selected papers from 10th International Soil Conservation Organization Meeting held May 24 - 29, 1999 at Purdue University and USDA-ARS National Soil Erosion Research Laboratory p580 - 585.

Donstova, K. M and Norton, L. D. (2002). Clay dispersion, infiltration and erosion as influenced by exchangeable $\mathrm{Ca}$ and $\mathrm{Mg}$. Soil Science. 167(3):184 - 193.

Emerson, W. W. and Chi, C. L. (1977). Exchangable calcium, magnesium and sodium and the dispersion of illites in water II. Dispersion of illites in water. Aust. J. Soil Res. 15:255 - 262.

Enloe, H. A. Graham, R. C and Sillete, S. C. (2006). Arboreal histology in old-growth redwood forest canopies. Northern California. Soil Sci. Soc. Am. J. 70: $408-$ 418.

FAO/IUSS. (2006). Guidelines for soil profile description. 4th edition. Rome.

Gee, G.W., and Bauder, J.,W. (1986). Particle size analysis. p. 404-407. In A. Klute (ed.) Methods of soil analysis. Part 1. 2nd ed. AgronMonogr. 9. ASA and SSSA, Madison, WI.

Mehlick, A., (1984). Mehlick 3 soil test extractant: a modification of Mehlick 2. Communications in Soil Science and Plant Analysis 15: 1409-1416.

Moss, R.P., (1957). Report on the classification of the soils found over sedimentary materials in Western Nigeria. Soil Survey Report. No. 67. Institute of Agricultural Research and Training, University of Ife, Ibadan.

Obi, J. C. and Ogunkunle, A. O. (2009). Influence of termite infestation on the spatial variability of soil properties in the guinea savanna region of Nigeria. Geoderma, 148: 357 - 368.

Obi, J. C., Ogunkunle, A. O. and Meludu, N. T. (2008). Effect of termite infestation on the farming system characteristics of an endemic area in the guinea savanna region of Nigeria. American-Eurasian Journal of Scientific Research 3 (1): 1 - 6. 
Olatunji, O.O.M., Ogunkunle, A.O., Tabi, A.O., (2007). Influence of parent material and topography on some soil properties in southwestern Nigeria. Nigerian Journal of Soil and Environmental Research 7:16.

Parkin, T. B. and Robinson, J. A. (1992). Analysis of lognormal data. Adv. Soil Sci. 20:193 325.

Phillips, J.D., (2007). Development of texture contrast soils by a combination of bioturbation and translocation. Catena 70: 92-104.

SAS Institute, (1999). SAS/STST User's Guide, Version 8, SAS Institute, Carry, NC.

Shaw, J. D., Packee, E. C. Sr and Ping, C. L. (2001). Growth of balsam poplar and black cottonwood in Alaska in relation to landform and soil. Canada Journal of Soil Resources. 31: 1793 - 1804.

Shukla, M. K. Slater, B, K., Lal, R. and Cepuder, P. (2004). Spatial variability of soil properties and potential management classification of a chernozemic field in lower Austria. Soil Science 169: 852-860.

Smyth, A. T. and Montgomery, R.F. (1962). Soil and Landuse in central Western Nigeria. Government printer. Ibadan. 265pp.

Soil Survey Staff (2006). Keys to Soil Taxonomy, 10th ed. United States Department of
Agriculture, Natural Resources Conservation Services, 331pp.

Souza, Z. M, Júnior, J. M and Pereira, G. T. (2009). Spatial variability of the physical and mineralogical properties of the soil from the areas with variation in landscape shapes. Braz. Arch. Biol. Technol. 52 (2): 305-316.

Tisdale, S. L., Nelson, W. L., Beaton, J. D. and Halvin, J. H. (1993). Soil fertility and fertilizer. 5th edition. Macmillian Publishing Company. New York.

Voortman, R. L. (1985). Guidelines on land evaluation for rainfed agriculture in Mozambique. Serie Terra e Agua, Comunicacao No. 30 INIA, Maputo and FAO, Rome.

Voortman, R. L. Brouwer, J. and Albersen, P. J. (2002). Characterization of spatial soil variability and its effect on millet yield on sudano-sahelian coversands in SW Niger. Staff Working Paper. WP-02-02. Centre for World Food Studies, The Netherlands.

Yilmaz, K., Kapur, S., Celik, I. and Ryan, J. (2005). clay minerals, $\mathrm{CA} / \mathrm{Mg}$ ratio and Fe-Al-Oxides in relation to structural stability, hydraulic conductivity and soil erosion in southeast Turkey. Turk. J. Agric. For. 29:29-37. 